\section{A misplaced medal? 50 years of unnecessary insulin treatment}

The unnecessary treatment of diabetes with insulin has been recognised increasingly. ${ }^{1}$ Large doses of insulin may be well tolerated without appreciable hypoglycaemia, for which several mechanisms have been postulated. The development of insulin antibodies may effectively neutralise exogenous insulin, and we describe a diabetic patient treated unnecessarily with insulin in whom this mechanism may have prevented hypoglycaemia.

\section{Case report}

In 1927 a 19 year old clerk presented with glycosuria and a history of thirst, polyuria, and weight loss. Diabetes mellitus was diagnosed. There was no family history of diabetes. He was treated with soluble and protamine zinc insulin and subsequently changed to 40 units lente insulin daily. Frequent analysis of urine showed good control.

In 1976 he attended with minor sepsis, and a random blood glucose estimation gave a value of $17.3 \mathrm{mmol} / 1(312 \mathrm{mg} / 100 \mathrm{ml})$. He continued with daily lente insulin, and postprandial glucose values varied from $4 \cdot 3$ to $5 \cdot 1$ $\mathrm{mmol} / \mathrm{l}(77$ to $92 \mathrm{mg} / 100 \mathrm{ml})$. He had no clinical or biochemical evidence of nephropathy or neuropathy and had minimal background retinopathy with a few scattered microaneurysms and an occasional dot haemorrhage. In 1978 he was awarded the Joslin Gold Medal in recognition of his successful treatment with insulin for more than 50 years.

In 1979 a random plasma C-peptide estimation with antibody $\mathrm{M} 1230^{2}$ showed an unexpected value of $2.5 \mathrm{nmol} / 1(7.6 \mathrm{ng} / \mathrm{ml})$, which suggested that he had residual beta cell function. Over the next two months his dose of lente insulin was reduced from 40 to 16 units daily. He remained asymptomatic with no ketonuria and blood glucose values of $4 \cdot 6-5 \cdot 4 \mathrm{mmol} / 1(83-97 \mathrm{mg} / 100$ $\mathrm{ml})$. A glucagon stimulation test $(1 \mathrm{mg}$ intravenously) was performed to assess pancreatic and beta cell function and plasma $\mathrm{C}$-peptide values measured before (total C-peptide) and after removal of insulin antibodies from the plasma by acid extraction (free C-peptide). The results (basal C-peptide values: total $0.86 \mathrm{nmol} / 1(2.6 \mathrm{ng} / \mathrm{ml})$, free $0.64 \mathrm{nmol} / 1(1.9 \mathrm{ng} / \mathrm{ml}) ; 20$ minutes after glucagon: total $0.96 \mathrm{nmol} / 1(2.9 \mathrm{ng} / \mathrm{ml})$, free $0.72 \mathrm{nmol} / 1(2.2 \mathrm{ng} / \mathrm{ml}))$ confirmed preservation of significant endogenous insulin secretion. One month after withdrawal of insulin an oral glucose tolerance test $(50 \mathrm{~g})$ confirmed impaired glucose tolerance (table). This was easily controlled with a carbohydrate restricted diet.

Results of oral glucose tolerance test $(50 \mathrm{~g})$ one month after withdrawal of insulin

\begin{tabular}{lccccc}
\hline & \multicolumn{5}{c}{ Time (min) } \\
\cline { 2 - 6 } & Fasting & 30 & 60 & 90 & 120 \\
\hline $\begin{array}{l}\text { Blood glucose }(\mathrm{mmol} / \mathrm{l}) \\
\text { Urinary sugar }\left({ }_{0}^{\circ}\right)\end{array}$ & $3 \cdot 5$ & $8 \cdot 5$ & $\begin{array}{c}10 \cdot 3 \\
0 \cdot 25\end{array}$ & $11 \cdot 0$ & $\begin{array}{c}8 \cdot 0 \\
0.5\end{array}$
\end{tabular}

Conversion: SI to traditional units-Blood glucose: $1 \mathrm{mmol} / 1 \approx 18 \mathrm{mg} / 100 \mathrm{ml}$.

During 52 years of insulin administration this patient had never had hypoglycaemia. The presence of circulating insulin antibodies was assessed using a modification of the method of Desbuquois and Aurbach, ${ }^{3}$ expressing the ratio of antibody bound ${ }^{125} \mathrm{I}$-insulin to total insulin as a percentage. The average percentage binding for our laboratory for a series of patients receiving lente insulin was $19 \cdot 8 \%$. This patient had a very high titre of antibodies, with a percentage binding of $54 \%$.

\section{Comment}

It is apparent in retrospect that this man developed the non-insulin dependent type of diabetes, sometimes known as maturity onset diabetes of youth. In 1927, however, it was assumed that he was insulin dependent, and this would never have been reviewed but for the fortuitous measurement of the plasma C-peptide concentration, which showed underlying pancreatic beta cell function. Surprisingly he had never had hypoglycaemia; this may be explained by neutralisation of the hypoglycaemic effect of exogenous insulin by the high titre of circulating insulin antibodies.

Most patients treated with conventional unpurified bovine insulins develop insulin antibodies. Highly purified insulins are much less immunogenic and conversion from conventional insulins often results in a fall in antibody titre and a reduction in insulin requirement." Studies in vitro show that insulin bound to antibody does not react with insulin receptors. ${ }^{5}$ Probably this mechanism allowed our patient $\widehat{\widehat{\overparen{ }}}$ to tolerate unnecessary insulin treatment for 50 years.

This case provides a salutory lesson that in certain cases treatment with insulin need not be a life sentence and illustrates the necessity $\mathbb{D}$ for regular review of the therapeutic management of diabetic patients. $T$ We have not dared to ask whether our patient should return his. Joslin medal.

We thank Mr R Mohamed, of the immunological unit, University ofo Aberdeen, for measurement of insulin antibodies, Dr Peter Ashby for the assay of plasma C-peptide, and Miss Lorna Forbes for secretarial help.

1 Kromann H, Borch E, Gale EAM. Unnecessary insulin treatment for diabetes. Br Med $\mathcal{f} 1981 ; 283: 1386-8$.

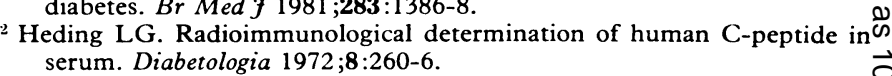

${ }^{3}$ Desbuquois D, Aurbach GD. Use of polyethylene glycol to separate free:and antibody-bound peptide hormones in radioimmunoassays. $\mathcal{F} \mathrm{Clin}-\overrightarrow{\mathrm{C}}$ Endocrinol Metab 1971;33:732-8.

4 Walfords S, Allison SP, Reeves WG. The effect of insulin antibodies ono insulin dose and diabetic control. Diabetologia 1982;22:106-10.

${ }^{5}$ de Pirro R, Fusco A, Spallone L, et al. Insulin antibodies prevent insulin-i receptor interactions. Diabetologia 1980;19:118-22.

(Accepted 21 December 1982)

Diabetic Department, Royal Infirmary of Edinburgh, Edinburgh EH3 9YW

MARY ARMITAGE, MB, BSC, senior house officer

BRIAN M FRIER, MD, MRCP, senior registrar (now consultant physician Gartnavel General Hospital, Glasgow)

LESLIE J P DUNCAN, BSC, FRCP, consultant physician

Correspondence to: Dr Mary Armitage, 17 Gladstone Terrace, Edinburgh $\frac{\widehat{\Phi}}{\triangle}$ EH9 1LS.

\section{Potential hazard of nebulised salbutamol in patients with haemoptysis}

Mild haemoptysis is fairly common in bronchiectasis but severe $\overline{\bar{O}}$ haemoptysis is rare and may be due to hypertrophy of the bronchia arteries, and hence bleeding may occur from the systemic circulation. Selective adrenoceptor agonists such as salbutamol and terbutaline. are commonly used as bronchodilators. These drugs, as well as relaxing smooth muscle in the bronchial wall, result in systemic and pulmonary vascular vasodilatation if given intravenously or by mouth. ${ }^{23}$ We describe a patient with bronchiectasis in whom nebulised salbutamol apparently increased the degree of haemoptysis:

\section{Case report}

A 54 year old woman with known bronchiectasis since the age of 8 was admitted to hospital with a 24 hour history of haemoptysis and a two day history of cough productive of purulent sputum. She gave no history of ches pain and there was no history of tuberculosis. She did not smoke. Clinica examination showed pronounced clubbing of fingers and toes. There was no clinical evidence of deep venous thrombosis. Pulse rate was $90 / \mathrm{min}$, of normal volume and regular, and blood pressure $140 / 80 \mathrm{~mm} \mathrm{Hg}$. In the chest coarse crepitations in the right mid and lower zones and bilateral expiratory rhonchi were heard. Investigations (full blood count) showed a haemoglobifo concentration of $14 \mathrm{~g} / \mathrm{dl}$ with a leucocytosis of $16.4 \times 10^{9} / 1(85 \%$ neutrophils $)$ a normal platelet count, and normal urea and electrolyte and liver function 2 values. Blood gas analysis showed slightly reduced arterial oxygen pressure only. An electrocardiogram was normal, as was the coagulation screen. tine tuberculin test elicited a grade 1 response. Peak expiratory flow rat was $1201 / \mathrm{min}$, forced expiratory volume in one second $\left(\mathrm{FEV}_{1}\right) 1.51$, forcee vital capacity (FVC) 3.01 , and $\mathrm{FEV}_{1}: \mathrm{FVC}$ ratio $50 \%$. Her drug treatmen consisted of salbutamol and ipratropium inhalers two puffs four times dailf each. She had been shown to have $15 \%$ improvement in ventilatory function after isoprenaline.

On admission treatment was instituted with an antibiotic and nebulise salbutamol $5 \mathrm{mg}$ six hourly (dose and method of administration of salbutamol routinely used in our patients admitted with reversible airflow obstruction The patient continued to have intermittent haemoptyses varying between 50 and $450 \mathrm{ml}$. Her haemoglobin concentration dropped to $10 \mathrm{~g} / \mathrm{dl}$ within a 